\title{
治験実施における薬剤師の係わりと その重要性に関する検討
}

\author{
杉山 正* 安田浩 二* 後 藤千寿* \\ 片 桐 義 博*
}

（受付：1999 年 3 月 4 日）

\begin{abstract}
A Study on the Importance of Clinical Trial Management by Pharmacists
\end{abstract}

\author{
Tadashi SUGIYAMA * Koji YASUDA * Chitoshi GOTO* \\ and Yoshihiro KATAGIRI* \\ * Department of Pharmacy, Gifu University Hospital \\ 40, Tsukasa-machi, Gifu, 500-8705 Japan
}

Under the new GCP, pharmacists should manage investigational new drugs. In Gifu University Hospital, pharmacists began to manage clinical trials in April 1997. The items of management at the registration of patients for clinical trials were follows : 1) content of consent forms, 2) number of registered patients, 3) presence of contraindicated medicine in patient's medication history, etc. The items of management at dispensing were follows : 1) accuracy of administration and dosage, 2) presence of contraindicated medicine on prescription, 3) presence of a consent form signed by patients, 4) prescription by registered investigators, etc.

From April 1997 to March 1998, pharmacists managed twenty-six clinical trials that included 122 patients. Pharmacists checked 46 incidences of contravention of the protocol in this period. Items of the contravention were: prescription of a medicine that is contraindicated for the investigational drug during the study, error in administration and dosage, excess of the number of patients registered, and prescription by non-registered investigators. Physicians corrected 42 contraventions following the instructions given by pharmacists. Pharmacists checked 38 items with questions about the procedure of clinical trials in this period. The contents of the question were prescription of the medicine that is limited to use during the study, imperfection of consent forms, imperfection of prescription, and doubtful standards for registration of patients. Physicians corrected 23 items in question following the recommendations given by pharmacists.

By this investigation, it became clear that the management of clinical trials by pharmacists is very important to ensure the quality of clinical trials in a hospital.

Key words : GCP, clinical trials management, pharmacist 


\section{緒論}

1997 年 4 月から施行された「医薬品の臨床試験 の実施の基準に関する省令（新 GCP）」の特徵は, 治験に係わるスタッフおよび組織の責務を明確化 したことである1)。それに伴い治験責任医師のみ ならず，治験分担医師，治験協力者の役割も明確 化されることになった．新 GCP には，「治験薬管 理者には薬剤師を当て, 実施医療機関で実施され る全ての治験の治験薬を管理させることを原則と する」と規定されている。この規定に従って, 岐 阜大学医学部附属病院では 1997 年 4 月より治験 薬の一元管理を薬剤部で行うこととなった。

薬剤部では，“GCP および治験実施計画書の規 定に従って，被験者に対して治験薬が正しく投与 されること”を目標に掲げ, 治験薬管理を通して 治験への積極的な関与を開始した。その後，実際 の治験薬管理の過程で治験実施計画書に違反する 処方などが多く認められた。今回，1997 年度に実 施された治験について，薬剤部での管理によって 明らかとなった治験実施上の問題点とそれに対す る薬剤師の対応状況を調查した. 調查結果をもと に薬剤部による治験薬管理の意義を評価し, 治験 を円滑かつ適正に実施するうえでの薬剤師の役割 および活動内容について考察を加えた。

\section{方 法}

\section{1. 岐阜大学医学部附属病院での治験管理}

本院には治験に係わる業務を行うために治験管 理室が設置されている，治験に関する事務および 審査委員会に関する事務は治験管理室の事務官が 担当している，治験管理室には専任および兼任の 薬剤師が配置されており，薬剤部において治験薬 の管理に関する業務を行っているほかに，モニ夕 リングへの対応などを担当している。

\section{2、薬剤部での治験薬管理の項目}

薬剤部での治験薬管理は，被験者の同意文書が 医師から薬剂部に提出された時点で，同意文書の 記載内容のチェック, 被験者の過去の薬歴から併 用禁止薬と併用制限薬の有無のチェック，および
予定症例数と登録された被験者数とのチェックを 行っている. 処方箋が発行された時点では, 同意 文書が提出された被験者であることの確認, 治験 責任医師あるいは治験分担医師による処方である ことの確認，治験薬の用法・用量・処方日数等の チェック，および他科からの処方を含め全ての処 方箋および注射箋を対象に併用禁止薬および併用 制限薬の処方のチェックを行っている．このほか に，投薬記録の作成および在庫管理を実施してい る.

\section{3. 治験実施上の問題点の調査}

1997 年 4 月から 1998 年 3 月に薬剤部において 管理した 45 治験について, 実施された治験の件 数, 実施症例数, 被験者に発行された処方箋およ び注射箋の枚数を調查した.また，治験薬管理の 過程で検出された問題点について, その内容およ び問題点に対する薬剤師の対応，それに伴う治験 実施上の変更状況について調查した。

\section{結果}

\section{1. 治験実施の件数と実施症例数}

薬剤部で管理した 45 治験のうち実施された件 数は 26 治験（57.8\%）であった。全 45 治験の契 約症例数 251 症例のうち実施された症例は 122 症 例 (48.6\%) であった. 19 治験に関しては, 特殊 な疾患を対象とした治験であり症例が認められな かった，あるいは被験者の同意が得られなかった ために治験が全く実施されなかった。

\section{2. 被験者に対する処方}

本院においては治験薬は単独の処方とすること となっている．被験者に対する治験薬の処方は， 処方箋が 300 枚, 注射箋が 103 枚であった。 また, 治験期間中に被験者に対して治験薬以外の処方箋 が 379 枚，注射嘎が 166 枚発行された。これらの 中には治験実施診療科以外の診療科から発行され た処方箋 45 枚および注射簙 4 枚が含まれていた (Table 1). 実施症例のうち, 治験薬のみが処方さ れていた症例は 27 例 (22.1\%)，他剤が併用され ていた症例は 95 例 (77.9\%) であった (Table 2). 
Table 1 治験実施期間中の処方箋と注射箋の枚数

\begin{tabular}{|c|c|c|c|}
\hline & & 治験薬の処方 & 治験薬以外の処方 \\
\hline 処 & 方 箋 & 300 & $379(45)^{*}$ \\
\hline & 射 箋 & 103 & $166(4)$ \\
\hline & 計 & 403 & $545(49)$ \\
\hline
\end{tabular}

* 治験実施診療科以外の処方（内数）

Table 3 違反の内容と対応（11 治験）

\begin{tabular}{lrrrr}
\hline \multirow{2}{*}{ 違反の内容 } & 件 & \multicolumn{2}{c}{ 修 } & 正 \\
\cline { 3 - 5 } \cline { 3 - 4 } & & & 有 & 無 \\
\hline 併用禁止薬の処方 & $27^{*}$ & $25^{*}$ & 2 \\
治験担当医師以外の処方 & 12 & 12 & 0 \\
投与量・投与期間の違反 & 6 & 4 & 2 \\
症例数超過 & 1 & $1^{* *}$ & 0 \\
\hline \multicolumn{1}{c}{ 計 } & 46 & 42 & 4 \\
\hline
\end{tabular}

* 他科からの処方 4 件含む

** 治験中止

\section{3. 治験実施上の問題点と薬剤師の対応}

1) 治験実施計画書違反

実施された 26 治験のうち治験実施計画書違反 が 11 治験（42.3\%）において延べ 46 件に認めら れた。 その内訳を Table 3 に示す。

被験者の登録時には予定症例数の超過が 1 件認 められた．医師への連絡によって治験が中止と なった。

処方箋が発行された時点では, 併用禁止薬の処 方が 15 症例で 27 件に認められた。併用禁止薬の 処方全てについて医師への確認が行われ，そのう ち 25 件において併用禁止薬は処方中止となった。 他の 2 件は治験薬の評価に影響を与えることがな い外用剤との判断からそのまま処方が継続された ため，医師にはその旨と理由を記録に残すよう指 示した．治験責任医師あるいは治験分担医師では ない医師による処方が 12 件に認められた。医師 へ確認した結果，全て治験責任医師あるいは治験 分担医師による処方に修正された．治験実施計画 書で定められた投与量あるいは投与期間を逸脱し た処方が 6 件に認められた．違反が認められた全 ての処方について医師への確認が行われ，4件に ついては治験実施計画書のとおりに修正された。
Table 2 被験者の治験薬以外の併用状沉

\begin{tabular}{cc}
\hline 治験薬以外の使用 & 症例数 $(\%)$ \\
\hline な し & $27(22.1)$ \\
あ & $95(77.9)$ \\
\hline 計 & $122(100.0)$ \\
\hline
\end{tabular}

Table 4 治験実施上の疑問と対応（13 治験）

\begin{tabular}{crrr}
\hline \multirow{2}{*}{ 項 目 } & \multirow{2}{*}{ 件 数 } & \multicolumn{2}{c}{ 修 } \\
\cline { 3 - 4 } & & 正 & 無 \\
\hline 同意文書の不備 & 17 & 17 & 0 \\
処方の記載不備 & 6 & 6 & 0 \\
併用制限薬の処方 & 5 & 0 & 5 \\
被験者選定の疑問 & 10 & 0 & 10 \\
\hline 計 & 38 & 23 & 15 \\
\hline
\end{tabular}

他の 2 件は受診日の都合上やむをえずそのまま処 方が継続されたため, 医師にはその旨と理由を記 録に残すよう指示した。

2 ）治験実施上の疑問点

治験実施計画書違反ではないが，治験実施上の 疑問点が 13 治験（50\%）において延べ 38 件に認 められた。その内訳を Table 4 に示す.

同意文書が提出された時点で被験者を登録する が，同意文書に代諾者の署名のみで被験者名の記 載漏れあるいは日付の記載漏れなどの不備が 17 件に認められた。医師に連絡を行った結果，全て の同意文書が修正された。被験者の登録時にその 時点までの投薬歴を参照したところ, 併用制限薬 が 2 症例に 5 件処方されていることが判明した。 医師への確認の結果，そのまま処方を継続して治 験を開始することとなったが，医師には治験の開 始前から併用制限薬を継続して投与している旨を 症例報告書に記載するよう指示した。

処方箋が発行された時点では，治験薬の組番の 記載漏れなどの処方の記載不備が 6 件に認められ た. 医師に連絡を行い全てが修正された.

被験者として, 治験実施診療科の研修医, 看護 婦あるいは治験依頼者の MR などの「社会的に弱 
い立場にある者」と考えられる者が選定されてい た治験が 10 件認められた. 当該者の同意が自発的 に行われたのか確認できなかったが，いずれも治 験薬の投与開始後に判明したために治験はそのま ま継続された。薬剤部から IRB へ報告し, IRBか ら全診療科に対して被験者の選定にあたっては十 分に配慮するように注意された。

\section{考察}

新 GCP では, 治験の原則として倫理性, 科学性 および信頼性の確保を求めている ${ }^{1 \sim 3)}$. 治験薬の適 切な管理は, 治験が「治験の原則」に基づき治験 実施計画書に従って確実に実施され評価を受ける うえで重要であり, 質の高い治験が行われるため の前提である。「新 GCP 普及定着総合研究」の「治 験管理・事務機能充実策検討作業班（班長：中島 新一郎 山梨医科大学教授)」では, 治験薬管理者 の業務として同意文書の確認，調剤，投薬管理表 の作成, 在庫管理および記録の保管などを挙げて (る4).これらのうち調剤時の処方監查は, 治験の 質を保証するうえで極めて重要な役割を担うと考 えられる。

本院では, 治験薬の投与法が治験実施計画書に 従って正しく行われていることを調剤時に確実に 確認するために, コンピュータに登録された治験 薬の情報から用法・用量・投与日数, 治験薬の規 格, 組番などを治験薬取扱説明書として出力し治 験薬とともに保管している，調剤時には治験薬取 扱説明書の内容を確認して処方監查を実施してい る.この結果，多くの治験において治験実施計画 書で定められた投与量あるいは投与期間を逸脱し た処方が検出されており，これらの処方監查は確 実に実施することが必要であると考える．検出さ れた違反の中では，検査日と被験者の受診日との 都合から，規定された投与期間を数日延長して治 験薬が投与された症例が 2 例あった。これらは， 治験薬の投与前に投与スケジュールおよび検査ス ケジュールを被験者に十分説明していれば回避で きた可能性があり，医師と被験者とのコミュニ ケーションが不十分であったことが推察された.

今回の調査では, 治験薬のみを処方されている
被験者はわずかであり, 約 $80 \%$ の被験者が治験薬 以外にも薬剤を投与されていることが明らかと なった。これに伴って，被験者に対して治験薬以 外の処方嘎が治験実施診療科および他の診療科か ら多く発行されている.したがって, 被験者の投 薬管理では治験薬の処方時のみならず, 治験薬以 外の薬剤が処方された場合も併用禁止薬の処方を 確実にチェックする体制が必要である.本院では, 処方オーダリングシステムから処方データを薬剤 部内に取り込んで全患者の薬歴データベースを作 成している5). 被験者の登録時には薬歴データ ベースを利用して併用禁止薬の処方の有無を チェックしている.また, 治験薬の処方および治 験薬以外の処方にかかわらず被験者に対して処方 箋が発行された場合には, コンピュータシステム によって併用禁止薬の処方のチェックを行ってい る.この結果, 併用禁止薬の処方が治験実施診療 科以外から処方された場合においてもチェックさ れ，併用禁止薬が投与されるのを未然に防止する ことができた. 本院の処方オーダリングシステム には，他科から処方された薬剤との組合せに関す る処方監查機能，および患者に治験が実施されて いることを知らせる機能は含まれていない.した がって, 薬剤部での投薬管理は治験の適正な実施 において極めて重要な役割を担っていると考えら れる。

本院では, IRB に履歴書を提出して審査された 治験責任医師あるいは治験分担医師のみが治験薬 を処方することになっているにもかかわらず，実 際の処方では治験責任医師あるいは治験分担医師 以外に医員あるいは医員（研修医）による処方が 多く認められた。これらの医師は GCP および治 験実施計画書等に十分に精通しているかは疑問で あり，これらの医師による治験薬の投与は治験の 倫理性, 科学性および信頼性を損なう可能性があ る.薬剤部では, 同意文書が提出された被験者お よびIRBにおいて承認された治験責任医師およ び治験分担医師をコンピュータに登録し管理して いる，調剤時には患者が同意文書を提出している 被験者であること, および処方医が治験責任医師 あるいは治験分担医師であることの確認を行って 
いる.このことは治験の倫理性, 科学性および信 頼性の確保に繫がると考えられる。

被験者の選定時の問題として,被験者として「社 会的に弱い立場にある者」が選択されていると考 えられる治験，あるいは同意文書に不備がある治 験が認められた.これらの原因の 1 つに, 本院で は被験者の選定および同意文書の取得が治験責任 医師あるいは治験分担医師に一任されていること が挙げられる、今後は, 同意文書を取得する際に は治験コーディネーターが立ち会い, 同意文書の 記載内容や被験者の選定方法についてもチェック するとともに，被験者に対して治験に関する説明 を行うことが必要になると考える6,7).

日本の治験では用法・用量違反, あるいは併用 薬違反などの重大なプロトコール違反が多いこと が報告されている8). 今回の調査では, 実施された 治験の $40 \%$ 以上において何らかの治験実施計画 書上の違反が発生していることが明らかとなっ た.これらの違反は, 被験者の安全性に重大な影 響を及ぼすだけでなく治験薬の評価にも重大な影 響を及ぼすものである。今回明らかとなった違反 の多くは, 治験責任医師あるいは治験分担医師が GCP および治験実施計画書を遵守して被験者を 選択し処方を行っていれば発生していなかったと 考えられる，川上らは，薬剤部における治験薬の 一元管理によって治験実施上の不備あるいはプロ トコール違反を検出することができ, 薬剤師が新 GCP の遵守に果たす役割の大きいことを報告し ている ${ }^{9}$. 本院においても, 薬剤師が本来の職能を 治験薬管理に発揮することによって治験実施上の 不備を検出することができた場合も多く認められ た.これらのことは治験の倫理性, 科学性および 信頼性の確保に繫がり, 薬剤師による治験薬管理 が新 GCP を遵守した治験実施に不可欠なことを 示すものと考える.

\section{結 論}

今回,我々は 1997 年度に実施された治験につい て, 薬剤部での管理によって明らかとなった治験 実施上の問題点とそれに対する薬剤師の対応状況 を調查した。この調査により，治験薬管理におい
て薬剤師の担う役割の重要性が実証された．治験 責任医師との実施手順に関する十分な打合せ, 被 験者の同意の確認，全診療科にわたる併用薬の確 認などの治験実施計画書遵守のチェック, 被験者 に対し治験に関する説明，さらに治験薬の服用状 況の確認などを行うことは薬剤師の重要な責務で あり ${ }^{10 \sim 14)}$, 薬剤師はこれらを通して治験の円滑か つ適正な実施に貢献する必要があると考えられ た。

\section{文献}

1）中野重行：新 GCP による新薬開発と医療従事者・ 臨床薬理学者の役割。臨床薬理, $29(1 \cdot 2): 7$ 14 (1998).

2）大須賀恵美子, 阿曾亮子, 大橋和史ほか：薬物治験 審査委員会 (IRB) による治験実施状況の調査に関す る検討一新 GCP 下の治験における IRB の役割一. 臨床薬理, 29(6)：843-853 (1998).

3）田中 慧：新 GCP の実施と薬剤師職能への期待. 月刊薬事, $40 ： 2241-2244$ (1998).

4）中島新一郎ほか：治験管理・事務機能充実策検討作 業班最終報告書. 平成 9 年度厚生科学研究「新 GCP 普及定着総合研究」最終報告書, ミクス, 東京, pp. 65-100 (1998).

5）杉山 正，柴山朋子，高野泰幸ほか：処方監查支援 システムの構築と運用一調凨支援システムの一環と して一. 病院薬学, 25:88-97 (1999).

6）井部俊子ほか：治験支援スタッフ養成策検討作業班 最終報告書. 平成 9 年度厚生科学研究「新 GCP 普及 定着総合研究」最終報告書, ミクス, 東京, pp. 101124 (1998).

7）末廣 勉，藤戸 博，森 昌斗：治験被験者用説明 文書の問題点の検討. 医薬ジャーナル, 34:30593065 (1998).

8）水島 裕：新しい治験の試み. 臨床薬理, $29(1 \cdot 2)$ ： 1-6 (1998).

9）川上英治, 二神幸次郎, 定金典明ほか：治験薬の一 元管理. 病院薬学, $25: 69-75$ (1999).

10）黒山政一, 横田慎一, 野中美和ほか: 北里大学東病 院における治験実施体制と薬郕師の役割. 月刊薬事, 40:2271-2276 (1998).

11）村田正弘：治験で薬剤師が果すべき役割と責任. 月 刊薬事, 39：1991-1995 (1997).

12）伊賀立二, 高柳理早, 中村幸一ほか：新 GCP に対応 した治験実施体制と薬郕師一 21 世紀の医薬品開発 に向けて一. 薬局, 49:1695-1701（1998）.

13）朝倉俊成，山岡秀人，野崎征支郎：治験薬管理にお ける薬剤師の役割. 日病薬誌, 34:191-195(1998).

14）神谷 晃：薬剤師治験コーディネーターの役割. 日 病薬誌, 34：1293-1299 (1998). 